\title{
DINAMIKA KELOMPOK PENDIDIKAN DI LEMBAGA PONDOK PESANTREN JAISYUL QURAN NAGREG
}

\author{
Abdul Haris \\ Universitas Islam Negeri Sunan Gunung Djati Bandung \\ Email: abdul.haris82@gmail.com
}

\begin{abstract}
ABSTRAK
Kajian makalah ini adalah untuk mendeskripsikan bahasan pokok dinamika kelompok di lembaga pendidikan. Dinamika kelompok disinyalir dapat dimanfaatkan sebagai alat manajemen kemajuan pondok pesantren jaisyul quran nagreg. sedangkan secara tujuan spesifik penelitian ini untuk memperoleh uraian penerapan konsep dinamika kelompok secara langsung dari sisi tujuan, sisi struktur, sisi tugas dan peran, sisi pembinaan, sisi kekompakan, sisi suasana, sisi tekanan dan sisi keefektifan di sebuah lembaga pondok tersebut. Metode yang digunakan adalah kuantitatif deskriptif dengan populasi pengambilan data seluruh pimpinan dan guru sejumlah 41 orang. Pengambilan data menggunakan instrumen skala likert yang telah diuji validitas dan realibilitasnya. Data dianalisis dengan rumus distribusi frekuensi relatif. Hasil yang di dapat dari penelitian ini adalah dinamika kelompok pondok jaisyul quran dilihat dari delapan aspek menunjukan kategori baik. Aspek Tujuan kelompok mencapai skor relatif 73\%. Aspek Struktur kelompok mencapai skor relatif 73\%. Aspek tugas dan peran kelompok mencapai skor relatif 73\%. Aspek pembinaan kelompok mencapai skor relatif 71\%. Aspek kekompakan kelompok mencapai skor relatif 69\%. Aspek suasana kelompok mencapai skor relatif 71\%. Aspek tekanan kelompok mencapai skor relatif 70\%. Dan aspek keefektifan kelompok mencapai skor relatif 68\%.
\end{abstract}

Kata kunci : dinamika, kelompok, pesantren

\begin{abstract}
The study of this paper is to describe the main discussion of group dynamics in educational institutions. The group dynamics can be used as a management tool for the progress of the Islamic Boarding School Jaisyul Quran Nagreg. while specifically the specific purpose of the this study is to obtain a description of the application of the concept of group dynamics directly in term of objectives, structure, duties and roles, coaching, cohesiveness, atmosphere, pressure and effectiveness in a boarding school. The method used is descriptive quantitative with a population of 41 teachers and leaders. Data retrieval using a Likert scale instrument that has been tested for validity and reliability. The result obtained from this study are the dynamics of the Pondok Jaisyul Quran group seen from eight aspects showing a good category. Aspect Goal group achieved a relative score of $73 \%$. The group stucture achieved a relative score of $73 \%$. Task and group role aspects achieved a relative score of $73 \%$. The group coaching aspect achieved a relative score of $71 \%$. The group cohesiveness aspect achieved a relative score of $69 \%$. the group atmosphere aspect achieved a relative score of $71 \%$. The group pressure aspect achieved a relative score of $70 \%$. The group effectiveness aspect achieved a relative score of $68 \%$.
\end{abstract}

Keywords : Dynamics, Groups, Pesantren 


\section{PENDAHULUAN}

Urgensi dari memahami dinamika kelompok adalah dapat mengetahui kualitas dari kelompok tersebut. Dinamika kelompok dijadikan alat dalam manajemen organisasi atau kelompok. dan dapat diketahui juga individu-individu yang ada dalam kelompok tersebut apakah dapat bekerjasama dan mampu mengelola untuk mencapai tujuan secara efektif, efisien dan produktif atau tidak.

Beberapa penelitian yang menggunakan dinamika kelompok sebagai alat, yaitu Hasil yang ditemukan Manggala dalam meneliti dinamika kelompok tani Agroforestry adalah rendah dalam menggerakan anggota kelompok mencapai tujuan. Unsur yang rendahnya tujuan, struktur, pembinaan, pengembangan, kekompakan dan suasana tekanan kelompok. sedangkan unsur yang kuat fungsi tugas dan keefektifan kelompok. menurut Manggala faktor yang menyebabkan rendahnya dinamika kelompok tani Agroforestry adalah kurangnya penyuluhan, tidak sesuainya materi penyuluhan dan kurangnya kepemimpinan kelompok tersebut ${ }^{1}$. Kedua, penelitian dinamika kelompok yang dilakukan Kusnani dkk terhadap penerima CSR PLN di Tarahan Lampung Selatan. Kusnani menjelaskan dinamika kelompok penerima CSR PLN rendah. Unsur-unsur yang rendahnya yaitu tujuan dan struktur kelompok belum dibuat secara spesifik. Fungsi dan tugas kelompok belum berjalan optimal. Dan tidak adanya tekanan kelompok yang

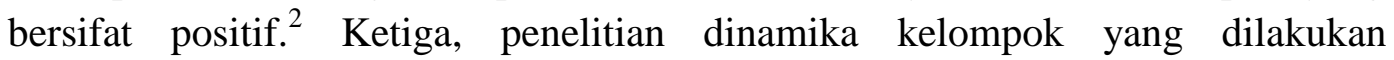
Sukmawati dkk untuk mengetahui peningkatan hasil belajar mahasiswa dalam perkuliahan PPBK. Ia menjelaskan dinamika kelompok dapat dimanfaatkan untuk meningkatkan mahasiswa dari sisi kualitas proses dan hasil belajar ${ }^{3}$.

Penelitian-penelitian di atas maksud dan tujuannya sesuai dengan yang dikemukakan Arifin dalam pengantar bukunya tentang dinamika kelompok. bahwa dinamika kelompok sebagai metode yang menyadarkan setiap individu dalam kelompok untuk bekerja secara optimal terlepas dari kekurangan dan kelebihannya masing-masing. Dinamika kelompok berupaya membuat situasi seluruh anggota kelompok merasa terlibat dalam mencapai tujuan bersama ${ }^{4}$. Dan sesuai dengan pendapat Sugiman "a major characteristics of group dynamics is in its research stance. A researcher of group dynamics enter real collectivity and

${ }^{1}$ Dyah Ekaprasetya manggala Rimbawati, Anna Fatchiya, and Basita Ginting Sugihen, "Dinamika Kelompok Tani Hutan Agroforestry Di Kabupaten Bandung," Jurnal Penyuluhan 14, no. 1 (2018): 92-103.

${ }^{2}$ Dedeh Kurniasih Kusnani, Pudji Muljono, and Amiruddin Saleh, "Dinamika Kelompok Penerima CSR PLN Tarahan Lampung Selatan,” Jurnal Penyuluhan 11, no. 2 (2015).

3 Indah Sukmawati et al., "Peningkatan Hasil Belajar Melalui Dinamika Kelompok Dalam Perkuliahan Pengajaran Psikologi Dan Bimbingan Konseling (PPBK),” Pedagogi: Jurnal Ilmu Pendidikan 13, no. 2 (2013): 10-18.

${ }^{4}$ Bambang Syamsul Arifin, "Dinamika Kelompok" (Pustaka Setia, 2015).hlm.19. 
collaborates with people there to improve or transform the field site" ${ }^{\text {, }}$ penelitian dinamika kelompok memasuki suatu kolektivitas nyata dan bekerjasama dengan orang-orang yang ada disana untuk memperbaiki dan mengubah situasi dan keadaan dilapangan.

Bersumber dari hasil observasi yang telah dilakukan penulis di pondok pesantren jaisyul quran terlihat fakta-fakta yang menunjukan dinamika kelompok guru berjalan kurang baik. Berikut ini fakta-fakta yang dimaksud :

1. Tim kerja bertugas tidak sesuai dengan perannya, begitu pula anggota dari masing-masing tim kerja tidak melaksanakan sebagaimana apa yang ditugaskan. Ada 6 tim kerja yang ditemui di pesantren jaisyul quran; dari mulai tim pembantu sampai tim utama.

2. Tidak diadakan rapat koordinasi. Padahal ragam rapat banyak, dimulai dari rapat yayasan, sampai dengan rapat unit.

3. Kekompakan anggota dari setiap tim kurang kompak. Tidak nampak canda gurau sebagai pertanda ke akraban muncul di saat waktu luang.

Dari permasalahan di atas, penelitian ini dilakukan bertujuan untuk mendapatkan informasi tentang Bagaimanakah dinamika kelompok di pondok pesantren jaisyul quran dan menganalisis perkembangan dinamika dilihat dari aspek :

1. Tujuan kelompok,

2. Struktur kelompok,

3. Tugas dan fungsi kelompok,

4. Pembinaan kelompok,

5. Kekompakan kelompok,

6. Suasana kelompok,

7. Tekanan kelompok dan

8. Keefektifan kelompok.

\section{METODE PENELITIAN}

Penelitian ini menggunakan metode kuantitatif deskriptif ${ }^{6}$. Secara umum peneliti mengikuti langkah-langkah sebagaimana berikut : pertama mendeskripsikan permasalahan secara sebab tujuan yang jelas untuk mengumpulkan data-data dan analisisnya, peneliti melakukannya dengan beberapa kali observasi ke lokasi. Kedua, menentukan prosedur penelitian meliputi populasi penelitian. Berdasarkan studi dokumentasi dilokasi, peneliti mendapatkan data jumlah semua pimpinan dan semua guru di pondok jaisyul quran, berjumlah 41 orang. Ketiga, mengumpulkan dan menganalisis data. Pengumpulan data dilaksanakan dengan mengunjungi pondok pesantren jaisyul

\footnotetext{
5 Toshio Sugiman, “Group Dynamics in Japan," Asian Journal of Social Psychology, 1998, https://doi.org/10.1111/1467-839X.00005.

${ }^{6}$ Mahmud, Metode Penelitian Pendidikan (Bandung: Pustaka Setia, 2011).hlm.101
} 
quran yang berlokasi di Jl.Pasanggrahan Kidul Rt 03 Rw 07 Desa Ganjarsabar Kecamatan Nagreg Kabupaten Bandung Jawa Barat.

Instrumen penelitian model skala likert variabel yang akan diukur dijabarkan menjadi indikator variabel. Dan indikator dijadikan titik tolak menyusun item-item instrumen. Setiap item dengan lima pilihan jawaban mulai dari tingkat sangat positif sampai sangat negatif ${ }^{7}$.

Analisis data dilakukan dengan cara memverifikasi data terlebih dahulu, yaitu dengan tahap editing dan coding. Editing adalah tahap memeriksa kembali kelengkapan jawaban yang diperoleh. Dan tahap coding adalah menaruh angka pada setiap jawaban. Angket diberikan kepada 41 orang guru yang diambil secara random. Kemudian di dapatlah data interval jawaban responden. Yang kemudian data tersebut dianalisis dengan menghitung rata-rata jawaban berdasarkan skoring setiap jawaban dari responden. Kemudian mentabulasi data, yaitu meletakan data pada tabel atau grafik. Hitung skor dan persentasi, jumlah skor yang diperoleh dari penelitian dibagi jumlah skor ideal (kriterium) seluruh item dikali persen. Dan mendeskripsikan data ke dalam tabel serta menentukan kriteria skor rata-rata yang diperoleh.

\section{KAJIAN TEORI}

\section{Dinamika Kelompok}

Dinamika secara bahasa diambil dari istilah fisika, yang memiliki arti bagian ilmu fisika yang berhubungan dengan benda yang bergerak dan tenaga yang menggerakan atau gerak (dari dalam); tenaga yang menggerakan semangat ${ }^{8}$. Dinamika kelompok dalam pengertian lain adalah gerak atau kekuatan yang dimiliki sekumpulan orang dalam masyarakat yang dapat menimbulkan perubahan dalam tata hidup masyarakat yang bersangkutan ${ }^{9}$. Gerak atau kekuatan apa saja yang dimiliki sekumpulan orang ? Gerak atau kekuatan yang ada dalam diri manusia adalah pengetahuan tentang diri dan dunianya untuk hidup lebih baik. Salah satu pengetahuan yang di dapat adalah melalui pendidikan ${ }^{10}$. Dan sekumpulan orang itulah yang dimaksud dengan Kelompok. Menurut Bambang berdasarkan dari beberapa definisi para ahli, kelompok adalah unit atau kumpulan individu baik dua atau tiga atau lebih yang terbentuk oleh sebab persepsi yang sama, tujuan, motivasi, dan fungsi lalu kemudian terjadi interaksi sehingga terjadinya ketergantungan satu sama lainnya ${ }^{11}$.

\footnotetext{
${ }^{7}$ Sugiyono, Metode Penelitian Pendidikan. Bandung, Metode Penelitian Pendidikan (Pendekatan Kuantitatif, Kualitatif, Dan R\&D), 2015.hlm.134

${ }^{8}$ Pusat Bahasa, "Kamus Besar Bahasa Indonesia (KBBI) Kamus Versi Online/Daring (Dalam Jaringan)," 2019, 2019, https://kbbi.web.id/.

${ }^{9}$ Slamet Santosa, Dinamika Kelompok (Bumi Aksara, 1992).hlm.5

${ }^{10}$ Muzzaky, "Dinamika Kelompok," Pendidikan, 2014.hlm.23

${ }^{11}$ Arifin, "Dinamika Kelompok.".hlm.20.
} 
Berikut ini konsep dasar dinamika kelompok yang dilihat berdasarkan ciriciri, jenis dan bentuknya, yaitu sebagai berikut ${ }^{12}$ :

1. Ciri-ciri kelompok sosial :

a. Adanya dorongan/motif yang sama pada setiap individu

b. Adanya kecakapan dan reaksi yang berbeda di antara individu

c. Adanya pembentukan struktur

d. Adanya penegasan norma pedoman tingkah laku

2. Jenis-jenis kelompok,

a. Jenis kelompok berdasarkan struktur yaitu kelompok formal dan kelompok informal $^{13}$. Kelompok formal adalah prosedur dan status resmi serta didukung peraturan secara tertulis. Struktur dan norma dirumuskan secara tegas. Penjabaran tujuan secara tertulis. Interaksi antar anggota resmi, bukan kekeluargaan. Sedangkan kelompok informal prosedur terbentuknya tidak secara resmi tetapi karena ikatan emosional. Interaksinya pun bersifat kekeluargaan.

b. Jenis kelompok berdasarkan fungsi. Yaitu kelompok tugas dan kelompok sosial. Kelompok yang fungsi utamanya menyelesaikan tugas disebut kelompok tugas. Dan kelompok yang fungsi utamanya mencapai kesejahteraan sosial disebut kelompok sosial.

3. Bentuk-bentuk kelompok

Berdasarkan bentuknya kelompok dapat dibedakan menjadi dua, yaitu kelompok primer dan kelompok sekunder. Bentuk kelompok primer adalah ciriciri utamanya saling mengenal antar anggota yang sangat erat sehingga tujuan individu menjadi tujuan kelompok. contoh nya kelompok keluarga, kelompok belajar, kelompok RT/RW dll. Bentuk kelompok sekunder adalah sebaliknya dari kelompok primer. Antar anggota tidak terlalu saling mengenal.

\section{Teori Dinamika Kelompok}

Terdapat 3 teori tentang dinamika kelompok, yaitu teori psikodinamika dari fungsi kelompok, teori sintalitas kelompok, teori prestasi kelompok. ${ }^{14}$

Teori psikodinamika dari fungsi kelompok, tokoh yang mengembangkannya adalah sullivan, adler, fromm, dan hornay. Menurut teori ini fungsi kelompok bukan sekedar kumpulan orang, tetapi satuan yang mempunyai ciri dinamika dan emosi. Menurut sigmund freud kelompok ini mempunyai tiga ciri yaitu membutuhkan/motif, tujuan/mekanisme, dan keterbatasan.

Teori sintalitas kelompok, tokoh penggagasnya adalah Cattel. Sintalitas artinya kepribadian khusus yang digunakan dalam kelompok. sintalitas kelompok

\footnotetext{
${ }^{12}$ Arifin.hlm.22-23

${ }^{13}$ Wildan Zulkarnain, Dinamika Kelompok: Latihan Kepimpinan Pendidikan, 2013.hlm.45

${ }^{14}$ Arifin, "Dinamika Kelompok."hlm.68-70.
} 
merupakan salah satu ciri kepribadian kelompok yang terlihat dan juga mempengaruhi lingkungan kelompoknya. Contoh sintalitas kelompok adalah kelompok siswa-siswa berprestasi dibidang matematika, maka dalam kelompok tersebut bersifat positif, yaitu melakukan penelitian sains, atau mengikuti olympiade matematika.

Teori prestasi kelompok, tokoh penggagasnya Stogdill. Teori prestasi kelompok yaitu input, variabel media, dan output. Proses terjadinya kelompok dimulai dari masukan (input) menuju keluaran (output) melalui variabel-variabel media. Input itu elemen interaksi sosial, hasil perbuatan, dan harapan. Sedangkan variabel media adalah elemen struktur formal, struktur peran. Dan output adalah prestasi kelompok.

\section{Pondok Pesantren}

Pondok pesantren merupakan lembaga pendidikan islam. Sekurangkurangnya memenuhi lima syarat; kiayi, pondok/kobong, santri, dan kitab yang diajarkan serta masjid ${ }^{15}$. Senada dengan pendapat Saebani bahwa pesantren adalah lembaga pendidikan formal yang mempersyaratkan kyai pesantren diurutan pertama, kemudian kedua ada pondok yaitu tempat tidur para santri, ketiga santrinya itu sendiri yang menuntut ilmu di pesantren, berikutnya kitab kuning yang menjadi ciri khas pembelajaran pesantren dan terakhir ada masjid sebagai tempat kegiatan belajar mengajar ${ }^{16}$.

Sesuai dengan perkembangannya, lembaga pendidikan pesantren mengalami kemajuan dari mulai hal kurikulum pesantren, profesionalitas para ustadz dan ustadzahnya sampai dengan penyediaan sarana prasarana yang modern, seperti misalnya perpustakaan, laboratorium dan media pendidikan lainnya.

\section{Pondok Pesantren Jaisyul Quran}

Pondok pesantren jaisyul quran terletak di jl.pasanggrahan rt 03 rw 07 desa ganjarsabar kecamatan nagreg kabupaten bandung. Berdiri sejak tahun 2016, didirikan oleh para kiyai untuk memenuhi kebutuhan masyarakat akan ilmu agama yang dipadukan dengan ilmu umum. fokus ungulannya tahfidz al-quran 30 juz. Jumlah Santri mukim smp - sma mencapai 300 santri dan jumlah pengajar 41 orang.

Berdasarkan observasi peneliti kelapangan dan informasi dokumen, pengelolaan pondok pesantren menggunakan manajemen tim kerja. Dimana terdapat kelompok-kelompok ustad dan ustadzah bekerja sesuai dengan tim kerjanya. Ada enam kelompok kerja yang peneliti cermati, yaitu tim kerja

\footnotetext{
${ }^{15}$ Tafsir Ahmad, Ilmu Pendidikan Dalam Perspektif Islam, PT Remaja Rosdakarya, 2016.hlm.290

${ }^{16}$ Hasan Basri and Ahmad Saebani, “Beni,” Ilmu Pendidikan Islam Jilid II, 2010.hlm 231
} 
akademik, tim kerja pengasuhan/keasramaan, tim kerja al-quran, tim kerja keuangan/admin, tim kerja bahasa dan tim kerja humas ${ }^{17}$.

\section{HASIL PENELITIAN}

Hasil penelitian ini akan menguraikan deskripsi data dinamika kelompok di pondok pesantren jaisyul quran nagreg yang meliputi delapan unsur, yaitu unsur tujuan, strukutur, fungsi dan tugas, pembinaan, kekompakan, suasana, tekanan, dan keefektifan. Untuk lebih jelasnya dapat dilihat pada tabel 1 dibawah ini.

Tabel 1

Dinamika Kelompok Pondok Pesantren Jaisyul Quran

\begin{tabular}{|c|c|c|c|c|}
\hline No & $\begin{array}{l}\text { Dinamika } \\
\text { Kelompok }\end{array}$ & Kriteria & Jumlah & Persentasi \\
\hline \multirow[t]{5}{*}{1} & \multirow[t]{5}{*}{ Tujuan } & Sangat tinggi & 14 & $34 \%$ \\
\hline & & Tinggi & 16 & $39 \%$ \\
\hline & & Sedang & 11 & $27 \%$ \\
\hline & & Rendah & 0 & $0 \%$ \\
\hline & & Sangat Rendah & 0 & $0 \%$ \\
\hline \multirow[t]{5}{*}{2} & \multirow[t]{5}{*}{ Struktur } & Sangat tinggi & 11 & $27 \%$ \\
\hline & & Tinggi & 19 & $46 \%$ \\
\hline & & Sedang & 11 & $27 \%$ \\
\hline & & Rendah & 0 & $0 \%$ \\
\hline & & Sangat rendah & 0 & $0 \%$ \\
\hline \multirow[t]{5}{*}{3} & \multirow[t]{5}{*}{ Fungsi dan Tugas } & Sangat tinggi & 13 & $32 \%$ \\
\hline & & Tinggi & 17 & $41 \%$ \\
\hline & & Sedang & 11 & $27 \%$ \\
\hline & & Rendah & 0 & $0 \%$ \\
\hline & & Sangat rendah & 0 & $0 \%$ \\
\hline \multirow[t]{5}{*}{4} & \multirow[t]{5}{*}{ Pembinaan } & Sangat tinggi & 13 & $32 \%$ \\
\hline & & Tinggi & 16 & $39 \%$ \\
\hline & & Sedang & 12 & $29 \%$ \\
\hline & & Rendah & 0 & $0 \%$ \\
\hline & & Sangat rendah & 0 & $0 \%$ \\
\hline \multirow[t]{4}{*}{5} & \multirow[t]{4}{*}{ Kekompakan } & Sangat tinggi & 15 & $37 \%$ \\
\hline & & Tinggi & 13 & $32 \%$ \\
\hline & & Sedang & 12 & $29 \%$ \\
\hline & & Rendah & 1 & $2 \%$ \\
\hline
\end{tabular}

${ }^{17}$ yayasan amal bhakti Qurani, "Dokumen Dan Arsip" (2019, 2019), 2019. 


\begin{tabular}{|l|l|l|c|c|}
\hline & & Sangat rendah & 0 & $0 \%$ \\
\hline 6 & \multirow{3}{*}{ Suasana } & Sangat tinggi & 11 & $27 \%$ \\
\cline { 3 - 5 } & & Tinggi & 18 & $44 \%$ \\
\cline { 3 - 5 } & & Sedang & 12 & $29 \%$ \\
\cline { 3 - 5 } & & Rendah & 0 & $0 \%$ \\
\cline { 3 - 5 } & & Sangat rendah & 0 & $0 \%$ \\
\hline 7 & \multirow{3}{*}{ Tekanan } & Sangat tinggi & 10 & $24 \%$ \\
\cline { 3 - 5 } & & Tinggi & 19 & $46 \%$ \\
\cline { 3 - 5 } & & Sedang & 12 & $29 \%$ \\
\cline { 3 - 5 } & Keefektifan & Rendah & 0 & $0 \%$ \\
\cline { 3 - 5 } & & Sangat rendah & 0 & $0 \%$ \\
\hline \multirow{3}{*}{8} & Sangat tinggi & 10 & $24 \%$ \\
\cline { 3 - 5 } & & Tinggi & 18 & $44 \%$ \\
\cline { 3 - 5 } & Sedang & 10 & $24 \%$ \\
\cline { 3 - 5 } & & Rendah & 3 & $7 \%$ \\
\cline { 3 - 5 } & & Sangat rendah & 0 & $0 \%$ \\
\hline
\end{tabular}

Sumber Data : Hasil Pengolahan Instrumen Penelitian 2020

Berdasarkan tabel di atas, hasil pengolahan data tujuan kelompok terlihat skor relatif lebih tinggi 34\% dan tinggi 39\% yaitu termasuk kategori tinggi dan sangat tinggi dan Kategori sedang mencapai skor relatif 27\%. Kategori rendah, sangat rendah skor relatif $0 \%$. Secara keseluruhan dinamika kelompok dilihat dari unsur tujuan adalah $73 \%$ atau termasuk kategori baik.

Struktur kelompok terlihat skor tertinggi $46 \%$ kategori tinggi dan $27 \%$ kategori sangat tinggi. Skor terendah mencapai skor relatif $27 \%$ kategori sedang dan $0 \%$ kategori rendah, sangat rendah. Secara keseluruhan dinamika kelompok dilihat dari unsur struktur adalah $73 \%$ atau termasuk kategori baik.

Fungsi dan Tugas kelompok terlihat skor tertinggi $41 \%$ kategori tinggi dan $32 \%$ kategori sangat tinggi. Skor terendah mencapai skor relatif $27 \%$ kategori sedang dan skor 0\% kategori rendah, sangat rendah. Secara keseluruhan dinamika kelompok dilihat dari segi unsur fungsi dan tugas kelompok adalah $73 \%$ atau termasuk kategori baik.

Pembinaan terlihat skor relatif tertinggi mencapai 39\% kategori tinggi dan skor 32\% kategori sangat tinggi. Skor relatif terendah mencapai skor 29\% kategori sedang dan skor $0 \%$ kategori rendah, sangat rendah. Secara keseluruhan dinamika kelompok dilihat dari segi unsur pembinaan adalah $71 \%$ atau termasuk kategori baik.

Kekompakan terlihat skor relatif tertinggi mencapai 37\% kategori sangat tinggi dan 32\% kategori tinggi. Kategori terendah mencapai skor relatif $29 \%$ kategori sedang dan skor $2 \%$ kategori rendah, skor $0 \%$ kategori sangat rendah. 
Secara keseluruhan dinamika kelompok dilihat dari segi unsur kekompakan adalah $69 \%$ atau termasuk kategori baik.

Suasana terlihat skor relatif tertinggi mencapai $44 \%$ kategori tinggi dan sangat tertinggi memperoleh skor relatif $27 \%$. Kategori terendah mencapai skor relatif $29 \%$ kategori sedang dan skor $0 \%$ kategori rendah, sangat rendah. Secara keseluruhan dinamika kelompok dilihat dari segi unsur suasana adalah $71 \%$ atau termasuk kategori baik.

Tekanan terlihat skor relatif tertinggi mencapai $46 \%$ kategori tinggi dan kategori sangat tinggi mencapai skor relatif $24 \%$. Kategori terendah mencapai skor relatif 29\% kategori sedang dan kategori rendah, sangat rendah dengan capaian skor relatif $0 \%$. Secara keseluruhan dinamika kelompok dilihat dari segi unsur suasana adalah $70 \%$ atau termasuk kategori baik keefektifan terlihat skor relatif tertinggi mencapai skor $44 \%$ kategori tinggi dan kategori sangat tinggi dengan skor capaian 24\%. Skor terendah mencapai $24 \%$ kategori sedang dan skor 7\% kategori rendah, serta skor $0 \%$ kategori sangat rendah. Secara keseluruhan dinamika kelompok dilihat dari segi unsur keefektifan adalah $68 \%$ atau termasuk kategori baik.

\section{PEMBAHASAN}

Supaya lebih jelasnya pembahasan tentang dinamika kelompok pondok pesantren jaisyul quran ditinjau dari unsur tujuan, struktur, tugas dan peran, pembinaan, kekompakan, suasana, tekanan dan keefektifan ${ }^{18}$. Aspek tujuan dalam dinamika kelompok sangat penting. Berkumpulnya beberapa individu dalam sebuah kelompok atau lembaga karena kesamaan tujuan. Tujuanlah yang menjadi Goals dalam gerak dan langkah untuk mencapainya ${ }^{19}$. Pendapat ini senada dengan Bambang S Arifin bahwa Tujuan merupakan gambaran hasil yang diharapkan oleh suatu kelompok. perpaduan dari tujuan-tujuan individual menjadi tujuan bersama dengan melakukan berbagai tugas untuk dapat mencapainya ${ }^{20}$.

Hasil penelitian dinamika kelompok dilihat dari unsur tujuan mencapai skor tertinggi $73 \%$ kategori baik. Responden sebahagian besar sudah melakukan pekerjaan penuh tanggungjawab, berorientasi pada tujuan yang sudah ditetapkan bersama, ada koordinasi dan tuntas dalam pengerjaannya sesuai dengan pedoman dari tujuan yang ditetapkan. Disamping itu skor terendah $27 \%$ kategori sedang atau cukup baik. Aspek tujuan dari dinamika kelompok relatif masih menyisakan masalah terutama dalam hal komunikasi/koordinasi antar kelompok. menurut Bambang $\mathrm{S}$ Arifin yang mengutip dari johnson menjelaskan bahwa tujuan

${ }^{18}$ I Suyatna and others, "Ciri-Ciri Kedinamisan Kelompok Sosial Tradisional Di Bali Dan Peranannya Dalam Pembangunan” (1982).hlm.i.

19 Stephen P Robbins and Timothy A Judge, "Perilaku Organisasi," Edisi Kesepuluh. Jakarta: PT Indeks Kelompok Gramedia, 2006.hlm.10

${ }^{20}$ Arifin, "Dinamika Kelompok.".hlm.55-56 
kelompok yang efektif salah satunya adalah miskomunikasi atau konflik tujuan yang terjadi dapat diselesaikan dengan baik. ${ }^{21}$ Secara keseluruhan dinamika kelompok pondok pesantren jaisyul quran dilihat dari segi tujuan mencapai skor $73 \%$ atau termasuk kategori baik.

Menurut Donelson struktur kelompok itu adalah peran, norma dan jaringan hubungan antar anggota yang menentukan dan mengatur kelompok ${ }^{22}$. Senada dengan Bambang S Arifin struktur kelompok dapat dianalisis dari tiga unsur, yaitu status, peran dan posisi. Dan faktor yang menentukan struktur kelompok adalah karena pertimbangan keperluan penyelesaian pekerjaan yang efektif. ${ }^{23}$

Fakta data hasil penelitian struktur kelompok di pondok pesantren jaisyul quran mencapai skor tertinggi 73\% termasuk kategori baik. Berdasarkan hasil pengukuran kelompok anggota melakukan pekerjaan sesuai dengan peran dan tugasnya dalam struktur kelompok. dan bekerja sesuai perintah dan keputusan dari pimpinan kelompok. disisi lain skor terendah mencapai 27\% kategori sedang atau cukup baik. Secara keseluruhan dinamika kelompok dilihat dari segi unsur struktur kelompok termasuk kategori baik. Menurut suyatna yang dikutip Bambang S Arifin bahwa fungsi dan tugas kelompok yang tercapai itu dapat dilihat dari kriteria-kriterianya yaitu menyampaikan kabar baik, harmonis, menyenangkan semua anggota, memiliki cara untuk melakukan, dan menyesuaikan dengan keadaan ${ }^{24}$.

Hasil penelitian dinamika kelompok di pondok pesantren jaisyul quran dilihat dari sub indikator fungsi dan tugas mencapai skor tertinggi $73 \%$ termasuk kategori baik. Antar anggota kelompok selalu berkoordinasi begitu pula dengan pimpinan $^{25}$. Asyik bekerja dalam tim. bekerja dengan banyak orang mampu mengahdirkan ide atau gagasan. Sementara itu skor terendah mencapai $27 \%$ kategori sedang atau cukup baik. Secara keseluruhan dinamika kelompok di pondok pesantren jaisyul quran relatif baik yaitu skor $73 \%$. Menurut Khodijah, suasana kelompok yang baik adalah suasana yang mampu mengahdirkan sikap saling menghargai, menghormati, menerima kekurangan dan kelebihan serta akrab atau bersahabat ${ }^{26}$. Ketenangan, etika, perasaan dan sikap dalam suasana yang akan membawa dinamika kelompok berjalan dengan baik. ${ }^{27}$

\footnotetext{
${ }^{21}$ Arifin.hlm.56-57

${ }^{22}$ Donelson R. Forsyth, “Group Dynamics 5th Edition,” Wandsworth Cengage Learning, 2010.hlm.144-145

${ }^{23}$ G. D. Mitchell, Dorwin Cartwright, and Alvin Zander, "Group Dynamics: Research and Theory," The British Journal of Sociology, 1955, https://doi.org/10.2307/586960.hlm.291-292

${ }^{24}$ Arifin, "Dinamika Kelompok."hlm.59

${ }^{25}$ PUTU CINTHYA WIRYANI PUDJA, I GEDE SETIAWAN A D I PUTRA, and WAYAN SUDARTA, "Tingkat Eksistensi Elemen-Elemen Subak Sebagai Sistem Sosial (Kasus Pada Subak Munggu Tegal Lantang, Desa Pererenan, Kecamatan Mengwi, Kabupaten Badung)," Jurnal Agribisnis Dan Agrowisata (Journal of Agribusiness and Agritourism), n.d.hlm.8.

${ }^{26}$ Nyayu Khodijah, "Psikologi Pendidikan," Jakarta: Rajawali Pers, 2014.hlm.103

${ }^{27}$ Arifin, "Dinamika Kelompok."hlm.59
} 
Fakta penelitian dinamika kelompok di pondok pesantren jaisyul quran dilihat dari aspek suasana mencapai skor tertinggi $71 \%$ termasuk kategori baik. Bekerja serius tetapi santai terdapat suasana kekeluargaan yang erat. Saling membantu dalam kesulitan dan selalu menghargai setiap aktifitas yang dilakukan antar guru. Disamping itu skor terendah mencapai 29\% kategori sedang atau cukup baik. Secara keseluruhan dinamika kelompok jaisyul quran adalah baik atau skor $71 \%$. Menurut Rimbawati pembinaan merupakan salah satu usaha untuk mempertahankan keberlangsungan kelompok. upaya yang dapat dilakukan adalah memenuhi sarana prasarana penunjang, supaya pembinaan berjalan secara efektif dan produktif ${ }^{28}$.

Fakta data hasil penelitian tentang pembinaan dalam dinamika kelompok pondok pesantren jaisyul quran mencapai kategori baik yaitu skor tertinggi $71 \%$. Semua kesulitan dapat diselesaikan dengan musyawarah. Bertukar pikiran menyampaikan ide dan gagasan dan keluh kesah dalam bekerja dapat terselesaikan di tempat pembinaan yaitu kesekretariatan atau kantor ${ }^{29}$. Disamping itu skor terendah $29 \%$ kategori sedang atau cukup baik. Secara keseluruhan dinamika jaisyul quran termasuk kategori baik. Menurut Rimbawati Kekompakan kelompok dapat mempersatukan gerak langkah dalam mencapai tujuan, pekerjaan yang dilakukan masing-masing akan dapat mengurangi rasa kebersamaan/solidaritas kelompok ${ }^{30}$.

Hasil penelitian dinamika kelompok di pondok pesantren jaisyul quran dilihat dari aspek kekompakan mencapai hasil skor relatif $69 \%$ atau termasuk kategori cukup baik. Selalu menjaga keutuhan kelompok untuk menghindari kesalahpahaman. Seimbang antara hak dan kewajiban yang dirasakan. Dan ada koordinasi antara pimpinan dengan anggotanya ${ }^{31}$. Disisi lain kekompakan jaisyul quran mencapai skor terendah $2 \%$ kategori rendah. Secara keseluruhan dinamika kelompok dari aspek kekompakan 69\% kategori baik. Menurut Andarwati yang dikutip Rimbawati menjelaskan keefektifan kelompok adalah ketika usaha yang dilakukan semua anggota kelompok dapat mencapai tujuan yang ditentukan. ${ }^{32}$ Meningkatnya kesejahteraan semua anggota kelompok dan tumbuhnya rasa

28 manggala Rimbawati, Fatchiya, and Sugihen, "Dinamika Kelompok Tani Hutan Agroforestry Di Kabupaten Bandung."hlm.92-103

${ }^{29}$ Indra Safari, "Pengembangan Model Pembinaan Profesionalisasi Guru Pendidikan Jasmani Di Sekolah Dasar Melalui Lesson Study Berbasis Kelompok Kerja Guru," Jurnal Penelitian Pendidikan 12, no. 2 (2011): 1-8.

30 manggala Rimbawati, Fatchiya, and Sugihen, "Dinamika Kelompok Tani Hutan Agroforestry Di Kabupaten Bandung."hlm.99

31 Marlinda Irwanti and Deddy Muharman, "Perspektif Baru Groupthink: Perbedaan Tingkat Pendidikan Dalam Proses Pengambilan Keputusan Kelompok," MIMBAR: Jurnal Sosial Dan Pembangunan 31, no. 1 (2015): 251-60.

32 manggala Rimbawati, Fatchiya, and Sugihen, "Dinamika Kelompok Tani Hutan Agroforestry Di Kabupaten Bandung."hlm.99 
memiliki serta rasa bangga pada kelompok menjadi ciri dinamika kelompok tersebut efektif. ${ }^{33}$

Fakta hasil penelitian dinamika kelompok di pondok pesantren jaisyul quran dilihat dari aspek kefektifan mencapai hasil skor relatif tertinggi $68 \%$, termasuk kategori baik dan 25\% kategori sedang. Setiap anggota kelompok mampu melakukan perbaikan dan meningkatkan produktifitas. Suasana saling menghargai produk yang dihasilkan dari setiap anggota. Dan yang berprestasi mendapatkan reward. Disamping itu skor terendah 7\% termasuk kategori sangat rendah. Secara keseluruhan dinamika kelompok jaisyul quran termasuk kategori baik.

\section{KESIMPULAN DAN SARAN}

\section{Kesimpulan}

Berdasarkan pembahasan dan penelitian di atas, dapat diambil kesimpulan sebagai berikut :

1. Dinamika kelompok pondok pesantren jaisyul quran dilihat dari aspek tujuan kelompok mencapai skor relatif $73 \%$ kategori baik

2. Dinamika kelompok pondok pesantren jaisyul quran dilihat dari aspek struktur kelompok mencapai skor relatif $73 \%$ kategori baik

3. Dinamika kelompok pondok pesantren jaisyul quran dilihat dari aspek tugas dan fungsi kelompok mencapai skor relatif $73 \%$ kategori baik

4. Dinamika kelompok pondok pesantren jaisyul quran dilihat dari aspek pembinaan kelompok mencapai hasil skor relatif $71 \%$ kategori baik

5. Dinamika kelompok pondok pesantren jaisyul quran dilihat dari segi aspek suasana kelompok mencapai hasil skor $71 \%$ kategori baik

6. Dinamika kelompok pondok pesantren jaisyul quran dilihat dari aspek kekompakan kelompok mencapai skor relatif 69\% kategori baik

7. Dinamika kelompok pondok pesantren jaisyul quran dilihat dari aspek keefektifan kelompok mencapai skor relatif $68 \%$ kategori baik.

8. Dinamika kelompok pondok pesantren jaisyul quran dilihat dari aspek tekanan kelompok mencapai skor relatif $70 \%$ kategori baik

\section{Saran}

Saran peneliti sampaikan untuk pimpinan, guru, peneliti dan mahasiswa adalah :

1. Bersumber pada hasil penggodokan data penelitian diatas tentang dinamika kelompok pondok pesantren jaisyul quran dilihat dari aspek tujuan memperoleh hasil baik, oleh karena itu diharapkan kepada pimpinan dan guru

${ }^{33}$ Connie Chairunnisa, "Kepemimpinan, Sistem Dan Struktur Organisasi, Lingkungan Fisik, Dan Keefektifan Organisasi Sekolah,” Jurnal Ilmu Pendidikan 19, no. 1 (2013). 
lebih memperbaiki pekerjaan penuh tanggungjawab, berorientasi pada tujuan yang sudah ditetapkan bersama, dan ada koordinasi supaya lebih efektif serta dinamika kelompok dapat menjadi lebih baik.

2. Bersumber pada hasil penggodokan data penelitian diatas tentang dinamika kelompok pondok pesantren jaisyul quran dilihat dari aspek struktur kelompok memperoleh hasil baik, oleh karena itu diharapkan kepada pimpinan dan guru lebih memperbaiki pekerjaan sesuai dengan peran dan tugasnya dalam struktur kelompok dan bekerja sesuai perintah dan keputusan dari pimpinan supaya lebih efektif serta dinamika kelompok dapat menjadi lebih baik.

3. Bersumber dari hasil penggodokan data penelitian diatas tentang dinamika kelompok pondok pesantren jaisyul quran nagreg dilihat dari aspek tugas dan fungsi kelompok memperoleh hasil baik, oleh karena itu diharapkan pada pimpinan dan guru lebih memperbaiki koordinasi antara pimpinan dengan anggota, senang bekerja dalam tim dan mampu mengahdirkan ide/gagasan supaya lebih efektif serta dinamika kelompok dapat menjadi lebih baik.

4. Bersumber dari hasil penggodokan data penelitian diatas tentang dinamika kelompok pondok pesantren jaisyul quran nagreg dilihat dari aspek pembinaan memperoleh hasil baik, oleh karena itu diharapkan kepada pimpinan lebih meningkatkan penyelesaian masalah dibawa ke forum rapat/musyawarah, bertukar pikiran menyampaikan ide atau gagasan atau keluhkesah di tempat pembinaan yaitu kantor atau kesekretariatan, supaya lebih efektif serta dinamika kelompok lebih baik.

5. Bersumber dari hasil penggodokan data penelitian diatas tentang dinamika kelompok pondok jaisyul quran nagreg dilihat dari aspek kekompakan kelompok memperoleh hasil baik. Oleh karena itu diharapkan pada pimpinan dan guru lebih meningkatkan keutuhan kelompok, seimbang antara hak dan kewajiban dan mampu koordinasi antara pimpinan dengan anggotanya, supaya lebih efektif serta dinamika kelompok menjadi lebih baik.

6. Buat peneliti sendiri penelitian ini bermanfaat untuk bisa lebih memperbaiki diri dan mampu mengembangkan keilmuawan dibidang yang sedang digeluti dan terutama ilmu dinamika kelompok suatu lembaga.

7. Buat teman-teman mahasiswa, penelitian ini semoga bisa menjadi rujukan pustaka dan bisa meneruskan pada penelitian selanjutnya tentang dinamika kelompok. 


\section{DAFTAR PUSTAKA}

Ahmad, Tafsir. Ilmu Pendidikan Dalam Perspektif Islam. PT Remaja Rosdakarya, 2007.

Arifin, Bambang Syamsul. "Dinamika Kelompok.” Pustaka Setia, 2015.

Bahasa, Pusat. "Kamus Besar Bahasa Indonesia (KBBI) Kamus Versi Online/Daring (Dalam Jaringan).” 2019, 2019. https://kbbi.web.id/karier.

Basri, Hasan, and Ahmad Saebani. "Beni." Ilmu Pendidikan Islam Jilid II, 2010.

Chairunnisa, Connie. "Kepemimpinan, Sistem Dan Struktur Organisasi,

Lingkungan Fisik, Dan Keefektifan Organisasi Sekolah.” Jurnal Ilmu Pendidikan 19, no. 1 (2013).

Irwanti, Marlinda, and Deddy Muharman. "Perspektif Baru Groupthink: Perbedaan Tingkat Pendidikan Dalam Proses Pengambilan Keputusan Kelompok." MIMBAR: Jurnal Sosial Dan Pembangunan 31, no. 1 (2015): 251-60.

Khodijah, Nyayu. "Psikologi Pendidikan.” Jakarta: Rajawali Pers, 2014.

Kusnani, Dedeh Kurniasih, Pudji Muljono, and Amiruddin Saleh. "Dinamika

Kelompok Penerima CSR PLN Tarahan Lampung Selatan.” Jurnal Penyuluhan 11, no. 2 (2015).

Mahmud. Metode Penelitian Pendidikan. Bandung: Pustaka Setia, 2011.

manggala Rimbawati, Dyah Ekaprasetya, Anna Fatchiya, and Basita Ginting

Sugihen. "Dinamika Kelompok Tani Hutan Agroforestry Di Kabupaten

Bandung." Jurnal Penyuluhan 14, no. 1 (2018): 92-103.

Mitchell, G. D., Dorwin Cartwright, and Alvin Zander. "Group Dynamics:

Research and Theory." The British Journal of Sociology, 1955. https://doi.org/10.2307/586960.

Muzzaky. "Dinamika Kelompok." Pendidikan, 2014.

PUDJA, PUTU CINTHYA WIRYANI, I GEDE SETIAWAN A D I PUTRA, and

WAYAN SUDARTA. "Tingkat Eksistensi Elemen-Elemen Subak Sebagai Sistem Sosial (Kasus Pada Subak Munggu Tegal Lantang, Desa Pererenan, Kecamatan Mengwi, Kabupaten Badung)." Jurnal Agribisnis Dan Agrowisata (Journal of Agribusiness and Agritourism), n.d.

Qurani, yayasan amal bhakti. "Dokumen Dan Arsip," 2019.

R. Forsyth, Donelson. "Group Dynamics 5th Edition." Wandsworth Cengage Learning, 2010.

Robbins, Stephen P, and Timothy A Judge. "Perilaku Organisasi." Edisi Kesepuluh. Jakarta: PT Indeks Kelompok Gramedia, 2006.

Safari, Indra. "Pengembangan Model Pembinaan Profesionalisasi Guru Pendidikan Jasmani Di Sekolah Dasar Melalui Lesson Study Berbasis Kelompok Kerja Guru.” Jurnal Penelitian Pendidikan 12, no. 2 (2011): 1-8. Santosa, Slamet. Dinamika Kelompok. Bumi Aksara, 1992. 
Sugiman, Toshio. "Group Dynamics in Japan." Asian Journal of Social Psychology, 1998. https://doi.org/10.1111/1467-839X.00005.

Sugiyono. Metode Penelitian Pendidikan. Bandung. Metode Penelitian Pendidikan (Pendekatan Kuantitatif, Kualitatif, Dan R\&D), 2015.

Sukmawati, Indah, Syukur Neviyarni, Yarmis Syukur, and Asrul Said.

"Peningkatan Hasil Belajar Melalui Dinamika Kelompok Dalam Perkuliahan

Pengajaran Psikologi Dan Bimbingan Konseling (PPBK)." Pedagogi: Jurnal Ilmu Pendidikan 13, no. 2 (2013): 10-18.

Suyatna, I, and others. "Ciri-Ciri Kedinamisan Kelompok Sosial Tradisional Di Bali Dan Peranannya Dalam Pembangunan," 1982.

Zulkarnain, Wildan. Dinamika Kelompok: Latihan Kepimpinan Pendidikan, 2013. 